\title{
On the velocity of sound in liquids
}

\section{T. Martini}

To cite this article: T. Martini (1888) On the velocity of sound in liquids, Philosophical Magazine Series 5, 26:162, 468-468, DOI: 10.1080/14786448808628299

To link to this article: http://dx.doi.org/10.1080/14786448808628299

曲 Published online: 29 Apr 2009.

Submit your article to this journal $\widetilde{ }$

Џ Article views: 3

Q View related articles $₫$ 
glass for electroscopes, by which these apparatus, especially those with gold and aluminium leaves, often fail in dry air ; for such glass acts like a condenser, and only discharges slowly. It is true that good conducting glass is difficult to meet with. Among 184 kinds which I tried I only found 19 which I could use, and only three of these were good: the trouble is, however, rewarded by the never failing working of the electroscope.

If the paper strips are cut off 1 to 2 millim. below the loop, and fine aluminium strips ( 4 millim. in breadth and 3 to 4 centim. in length, with rounded ends) are fixed on, an electroscope of extraordinary delicacy is obtained. My electroscope of this construction, with condensing-plates of $6 \cdot 5$ centim. diameter, gave a deflection of $55^{\circ}$ when the plates were touched with the poles of a bichromate element, while an ordinary aluminium electroscope showed only $15^{\circ}$.

With this aluminium electroscope we can show very distinctly the difference between the arrangement of elements in series and abreast. In the former case, with two Bunsen's elements, the leaves stand almost horizontal.-Zeitschrift für Phys. und Chem. Unterricht, vol. iv. p. 182. Beiblätter der Physik, No. 7, 1898.

ON THE VELOCITY OF SOUND IN LIQUIDS. BY T. MARTINI.

The principal results of the investigation are as follows :-

1. Wertheim's hypothesis that a cylindrical column of liquid vibrates like a solid cylinder is untenable; the smallness of Wertheim's numbers arises rather from the influence of the sides of the tubes.

2. The velocity of sound in water increases with the temperature within the ordinary limits of temperature.

3. The velocity of sound in other liquids increases with the temperature.

4. When gases, liquids, or solids are dissolved in water the velocity of sound increases; this is also the case with other liquids, such as alcohol, which absorbs water, or turpentine in which resins are dissolved.

5. The velocity of sound in saline solutions increases with the quantity of salt dissolved.

6. Solutions of different salts reduced to the same degree of concentration have different velocities.

7. If the same weight of different salts are dissolved in the same weight of water, very different numbers are obtained; these are much greater with salts containing water than with anhydrous salts.

8. If the same weights of anhydrous and of a hydrated salt are dissolved, the velocity of sound in the former is greater than in the latter.-Beiblätter der Physik, No. 8, 1888 ; from Atti del. R. Ist. Venet. (6) 6. 